\title{
Experimentation and modeling of soil evaporation in underground dam in a semiarid region
}

\section{Experimentação e modelagem da evaporação em barragem subterrânea numa região semiárida}

Fernandha Batista Lafayette ${ }^{1}$, Suzana Maria Gico Lima Montenegro ${ }^{1}$, Artur Paiva Coutinho ${ }^{2}$, Willames Soares ${ }^{3}$, Antônio Celso Dantas Antonino ${ }^{1}$, Bernardo Barbosa da Silva ${ }^{4}$ and Ana Emília Carvalho de Gusmão da Cunha Rabelo ${ }^{1}$

\author{
${ }^{1}$ Universidade Federal de Pernambuco, Recife, PE, Brasil \\ ${ }^{2}$ Universidade Federal de Pernambuco, Caruaru, PE, Brasil \\ ${ }^{3}$ Escola Politécnica- Universidade de Pernambuco, Recife, PE, Brasil \\ ${ }^{4}$ Universidade Federal de Campina Grande, Campina Grande, PB, Brasil
}

E-mails: fernandha.batista@gmail.com (FBL), suzanam.ufpe@gmail.com (SMGLM), arthur.coutinho@yahoo.com.br (APC),was@poli.br (WS), acdantonino@gmail.com (ACDA), bbdasilva.ufpe@gmail.com (BBS), anaerabelo@gmail.com (AECGCR)

Received: October 18, 2017 - Revised: August 24, 2018 - Accepted: October 10, 2018

\begin{abstract}
In semi-arid regions, there is a high evaporation, which leads to soil dryness, interfering in the availability of water in the soil. Usually it is difficult to measure and model the evaporation due to the complexity of the available methods, the low soil water content and the low concentration of water vapor in the air. This can also make it difficult to monitor and simulate the evapotranspiration in these regions. Thus, the Portable Chamber method is used to directly measure evaporation and evapotranspiration, because this technique allows real time estimation and in short time intervals, giving a more detailed estimation of those processes. The objective of this study was to evaluate the evaporation through the mass transfer in the soil in an underground dam under different water table depths and conditions of the semi-arid environment of Pernambuco State in Brazil, through the values predicted by the SiSPAT model and measured by the portable chamber method. For the purposing of modeling and also to better know the soil behavior, soil hydraulic properties were determined though the Beerkan method. The portable chamber method was applied for one of the first times in a semi-arid region of Northeastern Brazil, and it was consistent with the potential evaporation of bare soil, reaching about 1,800 mm per year. The SiSPAT model was quite satisfactory for simulation of soil evaporation in different conditions of the water table depth. The values found for soil evaporation with the simulation of the SiSPAT and the Portable Chamber (PC) method differed in 1.43\% and $4.44 \%$ for cases where the water table was at 0.20 and $1.20 \mathrm{~m}$ of depth, respectively.
\end{abstract}

Keywords: Mathematical modeling; Water and heat fluxes; SiSPAT; Beerkan Method; Portable Chamber; Rainwater harvesting.

\section{RESUMO}

Nas regiões semi-áridas, as altas taxas de evaporação interferem na disponibilidade de água no solo. Normalmente, é difícil medir e modelar a evaporação devido à complexidade dos métodos disponíveis, ao baixo teor de umidade do solo e à baixa concentração de vapor de água no ar. Isso também pode dificultar o monitoramento e a simulação da evapotranspiração nessas regiões. Assim, o método da Câmara Portátil (CP) é utilizado para medir diretamente a evaporação e a evapotranspiração em tempo real e em curtos intervalos de tempo, dando uma estimativa mais detalhada desses processos. O objetivo deste estudo foi avaliar a evaporação através da transferência de massa no solo numa barragem subterrânea sob diferentes profundidades e condições do lençol freático do ambiente semiárido do Estado de Pernambuco, nordeste do Brasil, através dos valores preditos pelo modelo SiSPAT e medidos pelo método de câmara portátil. Para o propósito da modelagem e também para conhecer melhor o comportamento do solo, as propriedades hidráulicas do solo foram determinadas pelo método de Beerkan. O método da Câmara Portátil apresentou resultados consistentes com o potencial de evaporação do solo nu no semiárido pernambucano/ Nordeste do Brasil, atingindo cerca de $1.800 \mathrm{~mm}$ por ano. O modelo SiSPAT foi bastante satisfatório para a simulação da evaporação do solo em diferentes condições da profundidade do lençol freático. Os valores encontrados para a evaporação do solo com a simulação do método SiSPAT e da Câmara Portátil (CP) diferiram em 1,43\% e 4,44\% para os casos em que o lençol freático estava em 0,20 e 1,20m de profundidade, respectivamente.

Palavras-chave: Modelagem matemática; Fluxo de água e calor; SisPAT; Método Beerkan; Câmara Portátil; Barragem subterrênea. 


\section{INTRODUCTION}

The estimation of soil evaporation is fundamental for planning the irrigation and management of the agriculture. In semi-arid regions, the evaporation may reach high values such as $2000 \mathrm{~mm} /$ year, which causes problems of soil dryness and yield loss for some crops. These aspects are usually associated with social problems, which are related to water shortage.

Some social technologies may be used in the semiarid to storage water, and evaporation may interfere in the storage and availability of water in the soil. Within the technologies used, underground dams (UD) are of fundamental importance in subsistence agriculture. The evaporation in these structures depends on the meteorological conditions, water table and soil hydraulic properties of the vadose zone. There are few studies on evaporation on this type of infrastructure (UD) also known as social technology based on rain water harvesting (QUILIS et al., 2009; LASAGE et al., 2008). Estimation of evaporation in these ecostructures is fundamental for quantifying the water balance, and then to help the adequate management aimed to water conservation purposes, to achieve higher crop yields and to control soil and groundwater and soil salinization processes, especially in the semiarid.

In these regions, the water vapor movement is an important part of the total water flow, where the water close to the soil surface is usually scarce (BITTELLI et al., 2008). In these conditions, the measurement and modeling of evaporation have shown difficulties. That happens due to the complexity of the more readily available methods, the low soil water content and the low concentration of water vapor in the air. These aspects may turn difficult the estimation of the evapotranspiration in the region.

Portable Chamber (PC) method is used to directly measure evaporation and evapotranspiration. This technique allows real time measurements and in short time intervals, giving a more detailed estimation of the evaporation and evapotranspiration processes. This technique has been used to measure water loss in tree tops (PONI et al., 1997), scrub (CENTINARI et al., 2009) and herbaceous crops (BALOGH et al., 2007; BURKART et al., 2007) and in forests in a semi-arid region (RAZ-YASEEF et al., 2010).There is no standardized form and size of such equipment, with a great variability in the contact area of those reported in the literature, such as $1.5 \mathrm{~m}^{2}$ (LUO et al., 2018), $0,35 \mathrm{~m}^{2}$ (MCLEOD et al., 2004), $0.28 \mathrm{~m}^{2}$ (CENTINARI et al., 2009), $0.54 \mathrm{~m}^{2}$ (PICKERING et al., 1993). Despite this, usually, the consistency of chamber measurements has been confirmed in the field by a comparison with other methods.

Mathematical modeling of water and vapor fluxes in soil may be performed through several numerical models. The SiSPAT model (Simple Soil-Plant Atmosphere Transfers) is an one-dimensional model (vertical), supplied with climate time series of temperature and air humidity, wind speed, global and atmospheric radiation and rainfall.

Since its first presentation in the literature (BRAUD et al., 1995a), SiSPAT has been continuously validated in different types of vegetation and soil. It has been subject to different climate and environmental conditions (MORET; BRAUD; ARRÚE, 2007; SOARES et al., 2013). Particularly, the SiSPAT model has been applied with good performance in the semiarid of Brazil (SOARES et al.,
2013; AMAZONAS et al., 2015). As usually, application of direct methods for estimation of evapotranspiration are difficult to apply and do not allow analyses of different management scenarios, validating a mathematical model is very important.

The objective of this study is to evaluate the evaporation in a UD, through the water transfer in the soil considering different water table depths and in the climate conditions of Pernambuco State semi-arid region. Both Portable chamber and mathematical model are used.

\section{MATERIALS AND METHODS}

The study area is located in the physiographic zone of "Agreste", district of Mutuca, in the city of Pesqueira, semi-arid region of Pernambuco State, in Brazil.

The Mutuca Valley is located within the semi-arid North East Brazil in which local communities rely on the groundwater as a resource for irrigation of crops, the predominant source of income.

The climate of this location is classified according to Köeppen as BShw' hot semi-arid, hyperxerophilic savanna, with the annual average temperature around $27^{\circ} \mathrm{C}$, annual average relative air humidity of $73 \%$ and average wind speed of $2.5 \mathrm{~m} / \mathrm{s}$ (MONTENEGRO; MONTENEGRO, 2006). This area is subject to high intensity rains, and occurring mostly during few months. These are concentrated in the first semester, with high variability in the rainfall regime, which has an annual average of approximately $630 \mathrm{~mm}$. The evaporation in the dry months (September - November) corresponds to approximately $49 \%$ and $51 \%$ of the total annual evaporation in the nearby cities of Caruaru and Arcoverde, respectively (ALMEIDA, 2006). Through data from Class A pan evaporation of the surrounding cities, it was observed that the annual average evaporation is $2,400 \mathrm{~mm}$ in the city of Arcoverde (35 km away from Pesqueira) and 2,111 $\mathrm{mm}$ in the city of Caruaru (100 km away from Pesqueira).

The goal of this article is to study the UD "Cafundó II", which has a maximum depth of $5.5 \mathrm{~m}$, axis extension of $42 \mathrm{~m}$ and an upstream range of about 1,300 m (ALMEIDA, 2006). The topography of the area upstream the underground dam where the experiment was located is flat and slightly undulated. The underlying geology of the region is characterised by crystalline basement of low hydraulic conductivity and low infiltration capacity. The poor hydraulic properties of the underlying crystalline basement mean groundwater storage and extraction is limited to deposits of alluvium within the base of the valley. Valley sediments are approximately 4-10m deep, extending within the valley base approximately $300 \mathrm{~m}$ in width and $15 \mathrm{~km}$ in length (MACKAY et al., 2005). The high permeabilities of the alluvial sediments provide for rapid groundwater movement under natural conditions (UNITED KINGDOM, 2006). However, groundwater flow and storage has been controlled in part by natural barriers to flow where hard basement rocks are exposed at the surface within the valley base and complemented by a series of underground dams installed at roughly even spacing along the valley. Cafundó II is one of these UD. 


\section{Soil physical characterization and experimental design}

Infiltration tests were performed aiming the estimation of the soil hydraulic properties at the study site. The infiltration tests under Beerkan methodology were performed along 9 points. In the upstream dam area were located the nine experimental points, A1 to A9, for performing the infiltration tests. Four points (B1 to B4) were chosen for setting the experimental device for the estimation of the soil evaporation (application of Portable Chamber method) (Figure 1).

The preliminary characterization of the soils was done through sample collection and laboratory analysis. The objective was to obtain the granulometry and soil specific mass. The granulometry was obtained through acombination of analysis by sedimentation and screening. The clay and silt fractions were determined by sedimentation. The coarsest fraction by sieving (EMBRAPA, 1997). To obtain the soil specific mass standard volume samples were extracted $\left(86.75 \mathrm{~cm}^{3}\right)$ using a cylindrical collector of UHLAND type (SOUZA et al., 2014). As the water table is at shallow depths, the soil was excavated so that the groundwater was reached. Then, the water table depth was measured using a metallic tape.

\section{Determination of soil hydrodynamic parameters: Beerkan Methodology}

For the modeling of water transportation in the soil, it is fundamental to know it's hydraulic properties, such as water retention curves $\theta(h)$ and hydraulic conductivity, $K(\theta)$. In this study, the hydrodynamic properties were determined by Beerkan infiltration method, detailed in Souza et al. (2008). This method estimates $\theta(h)$ and $K(\theta)$ parameters considering the texture and structure of the soil. In this semi-physical method, $\theta(h)$ and $K(\theta)$ are described analytically by five parameters: two related to shape, $\mathrm{m}$ or $\mathrm{n}$ and $\eta$, mainly related to the texture, and three normalizations $\theta \mathrm{s}, \mathrm{Ks}$ and hg, conditioned to the soil structure.

Beerkan method uses a simple circular ring of copper and provides the axisymmetric three - dimensional infiltration as a function of time, I3 ( $t$ ). The vegetation of the surface is removed

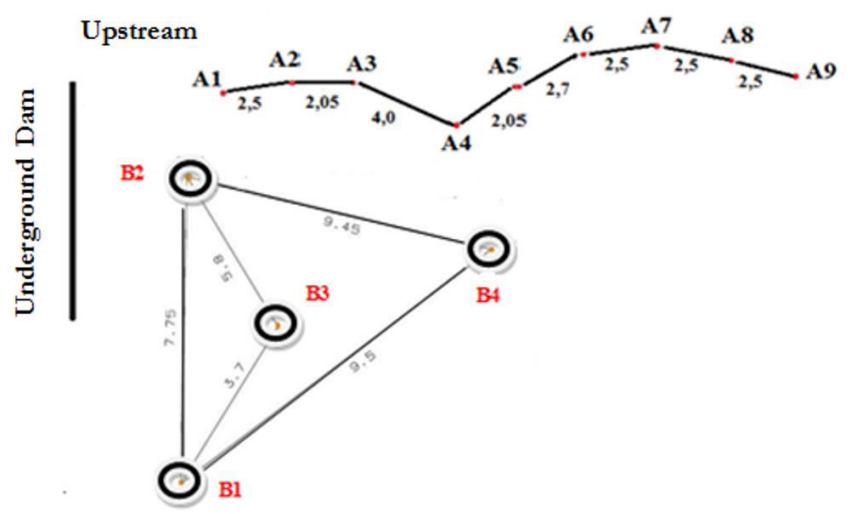

Figure 1. Points located upstream the underground dam (from A1 to A9) for soil hydraulic characterization and applications of the Portable Chamber Method (B1 to B4). Distance in meters. while the roots remain in place. Samples of the soil extracted with paddles and aluminum cans are collected to determine initial and final soil moisture. The ring is inserted into the soil to a depth of $1 \mathrm{~cm}$ in order to avoid lateral losses. In the beginning of the test, a known volume of water is added inside the ring and the time of infiltration of this volume is measured.

When the first volume is completely infiltrated, a second water volume is added to the cylinder, and the time necessary for infiltration is measured, in a cumulative form until the difference between five successive volumes is constant. Shape parameters are obtained from the porosity and particles size distribution curve while normalization parameters are identified by the infiltration curve, using the Best method - Beerkan Estimation of Soil Transfer parameters (LASSABATÈRE et al., 2006).

\section{Portable Chamber Method}

With this method, the water vapor flow is measured for small areas between the soil surface and the atmosphere (DUGAS et al., 1997). This is done through the insertion of a known volume of vegetation, soil surface, or both, and the measurement of an increase of vapor density inside the Portable Chamber (PC). The maximum rate of change in water vapor density with time is proportional to the evapotranspiration flow of the surface delimitated by the Portable Chamber (STANNARD, 1988). The evapotranspiration rate, $\mathrm{ET}(\mathrm{mm} /$ day), is calculated using the following equation 1:

$$
E T=86.4 \frac{M x V x C}{A}
$$

where:

M: maximum slope of the water vapor density curve (g.s / $\left.\mathrm{m}^{2}\right)$; V: volume inside of the Portable Chamber $\left(\mathrm{m}^{3}\right)$; C: Portable Chamber calibration factor; A: surface area covered by the Portable Chamber $\left(\mathrm{m}^{2}\right)$; 86.4: factor that transforms $\mathrm{g} / \mathrm{m}^{3} \mathrm{~s}$ in $\mathrm{mm} /$ day, using the water density as $1 \mathrm{~g} / \mathrm{cm}^{3}$.

Based on the model presented by Stannard (1988), the Portable Chamber was assembled by putting heat on an acrylic plate, which has a thickness of $4 \mathrm{~mm}$, in a wooden mold. Allowing the production of a piece with a semi-circle shape, with $1 \mathrm{~m}$ of diameter and $0.02 \mathrm{~m}$ of edge, inside volume of $0.2618 \mathrm{~m}^{3}$, and covers an area of $0.7854 \mathrm{~m}^{2}$.

Two fans were placed on opposite sides, inside of the Portable Chamber, to keep the movement of the air. This was needed to produce conditions inside of the Portable Chamber more similar to the naturals ones (HEIJMANS et al., 2004). A sensor was installed between each fan to measure the relative air humidity and temperature. This allows the calculation of the absolute humidity. Those sensors were also placed outside the Portable Chamber (Figure 2).

Due to the importance of keeping the sides of the Portable Chamber sealed, a thermal blanket was used to avoid air flow caused by the wind (CENTINARI et al., 2009). This thermal blanket is composed of a double thermal insulation plastic with aluminum foil in the lower part and a rubberized material with a thickness around $1 \mathrm{~cm}$ in the top part. This last one is used to avoid reflection that could interfere with the Portable Chamber application. It would cause, for example, an increase of soil 
surface temperature. With an internal and external radius of $1.0 \mathrm{~m}$ and $1.25 \mathrm{~m}$, respectively, the purpose of the blanket is to ensure the thermal isolation as well as to avoid vapor pressure losses inside the Portable Chamber.

The Portable Chamber was placed above four plain areas upstream the underground dam, which are marked here as B1, B2, B3 and B4 (Figure 1). A datalogger recorded measurements every second at average intervals of $8 \mathrm{~min}$. Between the intervals, the Portable Chamber was lifted up for a minimum time of $1 \mathrm{~min}$, in order to measure and standardize the air humidity and temperature.

The fluctuations of the incoming solar radiation and the air vapor pressure can considerably influence the Portable Chamber measurements (CENTINARI et al., 2009). Therefore the measurements were performed on sunny days. The Portable Chamber calibration factor was determined in the laboratory using the methods described by Stannard (1988). The procedure involved the evaporation of a known quantity of water in a glass recipient placed inside the PC. Simultaneously, the PC above the beaker estimated the evaporation.

This procedure was repeated many times in the laboratory. It was performed for each known evaporation rate produced by a heater, that was subjected to the following tensions: $50 \mathrm{~V}, 100 \mathrm{~V}$, $150 \mathrm{~V}$ and $220 \mathrm{~V}$. The measurements of evaporation by the scale and through the PC method were registered at each second and plotted one versus the other. The inclination of the best line that passes through the origin is used as a calibration factor.

\section{SISPAT Model (Simple Soil-Plant-Atmosphere Transfer Model) and simulation conditions}

The model is divided into four modules, which are: soil, atmosphere, the interface soil-plant-atmosphere and soil-plant (BRAUD et al., 1995a). SiSPAT is a computational code written in Fortran language. The detailed description of all water and energy transfer processes, as well as its equations, can be found in Soares (2009). The model may consider soil heterogeneity represented by homogeneous layers. In the current study, the soil was assumed homogeneous. The vegetation, when existent, is treated as a layer. Two energy balances are considered, one for the bare soil and another one for the vegetation. This study is not addressing areas with vegetation. The soil and atmosphere system is represented by two nonlinear equations, the soil surface energy balance and the continuity of mass flow through the soil surface, where soil matric potential and soil surface temperature are unknown (BRAUD et al.,1995b).

The SiSPAT model was used to simulate the soil evaporation in the upstream area of Cafundó II UD, in the same conditions as points A1 and A2. The PC method was also applied to compare the two methods in the period between October 13th and 19th of 2011. Two situations were considered for the model application. The first one with a $20 \mathrm{~cm}$ homogeneous soil layer (A1), water table at this depth, measured through groundwater level meter. In the second situation, the water table was placed at a $1.20 \mathrm{~m}$ depth (A2).

For the simulations of the transfer processes, it was considered the hypothesis that the soil profile is homogeneous. Prospections held on-site did not show heterogeneities on the observed scale. Therefore, the retention curve parameters ( $\theta r, \theta s, n, K g$, e Ks) and the hydraulic conductivity curve parameters resulting from the Beerkan method were considered unique for the whole soil profile.

The atmospheric data (Figure 3) used as upper boundary conditions for the simulations in the SiSPAT model (10/13/2011 to 10/19/2011) were: global solar radiation $\left(\mathrm{RG}, \mathrm{W} / \mathrm{m}^{2}\right)$; atmospheric radiation $\left(\mathrm{RA}, \mathrm{W} / \mathrm{m}^{2}\right)$; air temperature $(\mathrm{Ta}, \mathrm{K})$; specific humidity (q, $\mathrm{kg} / \mathrm{kg}$ ); wind velocity $(\mathrm{U}, \mathrm{m} / \mathrm{s})$. The values of $\mathrm{RG}$, Ta and $\mathrm{U}$ were provided by ITEP laboratory, from a hydrometeorological station located $35 \mathrm{~km}$ away from the study area.

The data of a station $35 \mathrm{~km}$ away was used because the nearest stations presented did not have time series with continuous measurement and with consistent data for the place where the experiments were carried out. More precisely, there are no meteorological stations/data collection platforms at a distance of less than $35 \mathrm{~km}$ from the study site. However, studies indicate that the region is hydrologically homogeneous (KELLER FILHO et al., 2005). Despite the distance, the station used is within a region of same hydrological behavior as that of the study site.

During the considered simulation period there weren't any rainfall events in the study area.

RA value was obtained in function of Ta through Equation 2:

$R A=\varepsilon \sigma\left(T_{a}\right)^{4}$

where,

$\sigma:$ Stefan-Boltzman constant (5.67.10-8W/m2K4)

$\varepsilon$ : atmospheric emission, obtained through Brutsaert expression (1975) adjusted by Silva et al. (2002)

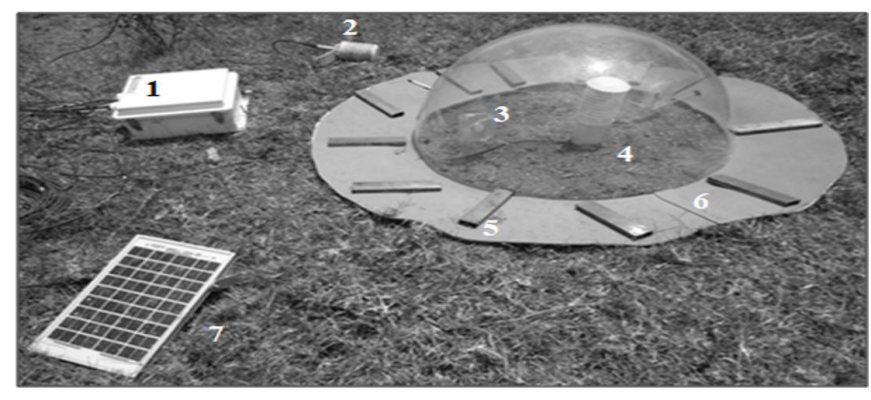

Figure 2. Portable Chamber application. 1. Data center - Datalogger, 2. air humidity, and temperature sensors, 3. Fans, 4. Portable Chamber, 5. Iron bars, 6. Thermal blanket, 7. Solar panel.

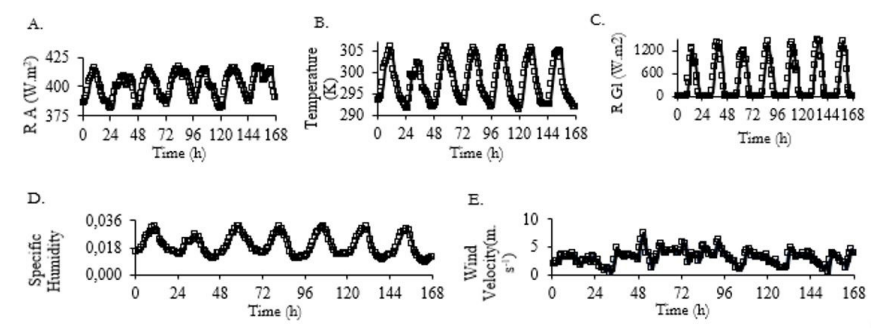

Figure 3. SiSPAT atmospheric input data: (A) atmospheric radiation, (B) air temperature, (C) global radiation, (D) specific humidity, (E) wind velocity. 
ea is the vapor pressure $(\mathrm{Pa})$ (Equation 3):

$$
\varepsilon=\left[1,697-0,58\left(\frac{e_{a}}{T_{a}}\right)^{\frac{1}{7}}\right]
$$

The vapor pressure was estimated through the air temperature.

The atmospheric pressure (Patm) was determined as a function of the temperature. The specific air humidity (q) was estimated from this variable through equation (4).

$q=\frac{0.622 \times e_{a}}{P_{a t m}-0.37 \times e_{a}}$

The soil water retention curves, $\theta(\mathrm{h})$, and the hydraulic conductivity, $K(\theta)$, were described, respectively, by Brooks and Corey (1964) and van Genuchten (1980) models (equations 5 and 6):

$\left(\frac{\theta-\theta_{r}}{\theta_{s}-\theta_{r}}\right)=\left(1+\left(\frac{h}{h_{g}}\right)^{n}\right)^{-\left(1-\frac{2}{n}\right)}$

$$
K(\theta)=K_{s}\left(\frac{\theta-\theta_{r}}{\theta_{s}-\theta_{r}}\right)^{\eta}
$$

where $\theta$ is the volumetric soil water content, $\theta \mathrm{r}$ and $\theta$ s the saturated and residual volumetric soil water content, respectively; $h$ the matrix soil water potential; hy the bubbling pressure, from where the water starts to drain the soil; $\mathrm{n}$ the shape parameters; Ks the soil saturated hydraulic conductivity and $\eta$ the shape parameter for the hydraulic conductivity curve.

Through the measured data, soil temperature and matric potential, a linear interpolation was performed in order to obtain the values at different depth at soil profile. The soil temperature profiles used as input data for the simulation of the initial conditions of both situations are presented in Table 1 .

The SISPAT Model uses as upper boundary condition the temperature information, which should be exclusively in the Celsius unit. Likewise, for the lower boundary condition, the SISPAT model uses the temperature data on the Kelvin unit.

In the simulation for the two situations, a soil potential matrix profile in hydrostatic equilibrium conditions was used as initial setup (Table 2).

The daily values of soil temperature used as input data for the lower boundary condition are presented in Table 3 . The soil temperature data was based on values obtained from sensors installed at 10 and $20 \mathrm{~cm}$ depth, on October 15th 2011, represented by the third simulation day. The soil matric potential used as the lower boundary condition was assumed on the basis of saturation for the two modeling conditions.

\section{RESULTS AND DISCUSSION}

\section{Soil characterization}

The soil physic characterization, from the analyses of the granulometric curve, shows that in the study area there is a prevalence of sandy material (Table 4).

In table 5 the values of global density and porosity $(\phi)$ of the points in the study area used for simulation on the SiSPAT are presented. The global density was achieved by the volumetric ring method.

Figure 4 demonstrates that the infiltration in point A1 occurred in $850 \mathrm{~s}$ to an accumulated infiltration volume of $160 \mathrm{~mm}$, and in point A2 it took about $960 \mathrm{~s}$ for the total infiltration of the accumulated infiltration volume of $185 \mathrm{~mm}$. The points presented an average infiltration velocity of $1.8 \cdot 10^{-2} \mathrm{~cm} \cdot \mathrm{s}^{-1}$, reasonable for sandy soil. Point 5 was an exception. It presented an average

\begin{tabular}{|c|c|c|c|c|c|c|c|c|c|c|c|c|c|c|c|}
\hline Depth $(\mathrm{cm})$ & 0 & 4 & 8 & 12 & 16 & 20 & 30 & 40 & 60 & 70 & 80 & 90 & 100 & 110 & 120 \\
\hline $\begin{array}{l}\mathrm{T}\left({ }^{\circ} \mathrm{C}\right) \\
\text { conditions } 1\end{array}$ & 24.2 & 24.4 & 24.6 & 24.8 & 24.7 & 24.6 & - & - & - & - & - & - & - & - & - \\
\hline $\begin{array}{l}\mathrm{T}\left({ }^{\circ} \mathrm{C}\right) \text {, } \\
\text { conditions } 2\end{array}$ & 23.6 & 23.8 & 24.0 & 24.7 & 24.9 & 25.2 & 26.4 & 26.1 & 25.6 & 25.4 & 25.4 & 25.4 & 25.4 & 25.3 & 25.3 \\
\hline
\end{tabular}

Table1. Soil temperature initial conditions for conditions 1 and 2.

Table 2. Soil matric potential profile used as initial condition: Condition 1 (A) (water table a depth of $0.20 \mathrm{~m}$ ); Condition 2 (B)

\begin{tabular}{|c|c|c|c|c|c|c|c|c|c|c|c|c|c|c|c|}
\hline Depth $(\mathrm{cm})$ & 0 & 4 & 8 & 12 & 16 & 20 & 30 & 40 & 60 & 70 & 80 & 90 & 100 & 110 & 120 \\
\hline $\begin{array}{l}\mathrm{h}(\mathrm{m}), \\
\text { Condition } 1\end{array}$ & -2.06 & -1.65 & -1.24 & -0.82 & -0.41 & 0.0 & & & & & & & & & \\
\hline $\begin{array}{l}\mathrm{h}(\mathrm{m}), \\
\text { Condition } 2\end{array}$ & -12.3 & -11.9 & -11.5 & -11.1 & -10.7 & -10.3 & -9.2 & -8.2 & -6.2 & -5.1 & -4.2 & -3.1 & -2 & -1.1 & 0.0 \\
\hline
\end{tabular}
(water table a depth of $1.20 \mathrm{~m}$ ).

Table 3. Input data of the SiSPAT model for lower boundary condition.

\begin{tabular}{ccccccccc}
\multirow{2}{*}{$\mathbf{T}\left({ }^{\circ} \mathbf{K}\right)$} & Condition 1 & 297.8 & 300.6 & 301 & 301.2 & 301.4 & 301.3 & 301.1 \\
& Condition 2 & 298.46 & 298.8 & 299.2 & 299.4 & 299.6 & 299.4 & 299.2 \\
\hline
\end{tabular}


value of infiltration velocity higher than $5 \cdot 2 \cdot 10^{-2} \mathrm{~mm} \cdot \mathrm{s}^{-1}$. This may have been due to the occurrence of stone in the layer adjacent to the surface.

In Table 6 are presented the values of hydraulic characterization of the soil from the infiltration tests applying the Beerkan method. The saturated water content was estimated as equivalent to $90 \%$ of total porosity values, according to Braud et al. (2009). The parameters of the points A1 and A2 were used for the modeling purpose for the two different conditions.

\section{Soil evaporation - Portable Chamber Method}

Figure 5 presents the measurements made with the PC method for the temperature inside the $\mathrm{PC}$ and also of relative air humidity inside and outside it for the first measurement of point B1 as a function of time. It exhibits the vapor density curve, which, according to Stannard (1988), has a proportional behavior as related to evaporation (Figure $5 \mathrm{~A}$ and $5 \mathrm{~B}$ ). The air

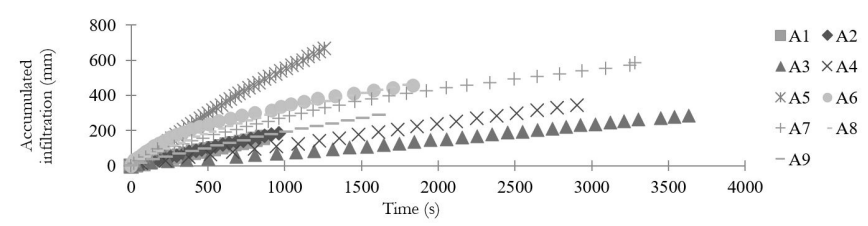

Figure 4. Accumulated infiltration in function of the time for the nine experimental points. temperature inside the Portable Chamber (PC) varied from $29.5^{\circ} \mathrm{C}$ to $30.8{ }^{\circ} \mathrm{C}$, that is, an increase higher than $4 \%$ in a time lap of $10 \mathrm{~min}$. The maximum inclination of the increase of vapor density with time was $0.0797 \mathrm{~g} / \mathrm{m}^{3} \mathrm{~s}$, with $\mathrm{R}^{2}$ equal to 0.9973 . The decrease of relative air humidity inside the PC was triggered by its rise for about 1 minute, after each application, to obtain and standardize air humidity and temperature with the external environment.

The applications from group B1 and others groups are presented in Table 7, which shows the initial and final values of temperature and relative air humidity inside the PC, the maximum slope of vapor density with time and soil evaporation. The calibration factor found in the laboratory was 1.24. The area and volume involved by the PC were $0.785 \mathrm{~m}^{2}$ and $0.262 \mathrm{~m}^{3}$, respectively.

Analyses were performed in a representative period of the meteorological behavior of the region at the beginning of the dry period. The slopes of vapor density with time and evaporation of the bare soil were higher in the application points of the group B2. This happened because of: i) In the point, the water table location is at $0.20 \mathrm{~m}$; and ii) Measurements with the $\mathrm{PC}$ at point B2 were performed at the time of more influence of the solar radiation (from 00:20pm to $1: 10 \mathrm{pm}$ ).

The highest daily evaporation was measured near to a time of 00:39 pm. Between the applications performed, the group B2 presented the highest average, $5.53 \mathrm{~mm}$.d-1. This point was close to the temporary rivulet, where the water table was at a depth of approximately $0.20 \mathrm{~m}$. As the soil was with high moisture content, the soil evaporation was specially conducted by the atmospheric meteorological conditions, independently of the soil physic

Table 4. Granulometry and texture classification of the soil of the study area.

\begin{tabular}{|c|c|c|c|c|c|c|c|c|c|}
\hline \multicolumn{2}{|c|}{$\begin{array}{c}\text { Diameter } \\
(\mathrm{mm})\end{array}$} & \multirow{2}{*}{$\begin{array}{c}<0.002 \\
\text { clay }\end{array}$} & \multirow{2}{*}{$\begin{array}{c}0.05 \\
\text { silt }\end{array}$} & \multirow{2}{*}{$\begin{array}{c}0.1 \\
\text { Very Fine } \\
\text { Sand } \\
\end{array}$} & \multirow{2}{*}{$\begin{array}{c}0.25 \\
\text { Fine Sand }\end{array}$} & \multirow{2}{*}{$\begin{array}{c}0.5 \\
\begin{array}{c}\text { Medium } \\
\text { Sand }\end{array}\end{array}$} & \multirow{2}{*}{$\begin{array}{c}1 \\
\text { Coarse } \\
\text { Sand } \\
\end{array}$} & \multirow{2}{*}{$\begin{array}{c}2> \\
\text { Very Coarse } \\
\text { Sand }\end{array}$} & \multirow{2}{*}{ Classification } \\
\hline $\mathrm{Sa}$ & & & & & & & & & \\
\hline A1 & $\%$ & 3.5 & 7.7 & 7.3 & 23.8 & 20.8 & 21.4 & 15.4 & Sandy \\
\hline A2 & $\%$ & 3.5 & 10.6 & 4.5 & 13.0 & 14.3 & 23.5 & 30.6 & Sandy \\
\hline A3 & $\%$ & 5.9 & 12.1 & 14.1 & 40.4 & 16.5 & 6.9 & 4.2 & Sandy \\
\hline A4 & $\%$ & 5.9 & 11.1 & 16.2 & 31.1 & 16.4 & 11.4 & 7.9 & Sandy \\
\hline A5 & $\%$ & 8.2 & 16.0 & 8.7 & 17.2 & 16.2 & 18.0 & 15.7 & Sandy Loam \\
\hline A6 & $\%$ & 4.7 & 11.7 & 6.3 & 15.9 & 15.6 & 23.4 & 22.4 & Sandy \\
\hline A7 & $\%$ & 11.7 & 32.6 & 17.3 & 25.6 & 7.8 & 3.1 & 1.9 & Sandy Loam \\
\hline A8 & $\%$ & 4.7 & 12.3 & 8.5 & 14.7 & 15.4 & 22.0 & 22.4 & Sandy \\
\hline A9 & $\%$ & 2.3 & 9.3 & 9.6 & 27.9 & 18.3 & 14.8 & 17.8 & Sandy \\
\hline
\end{tabular}

Table 5. Global Density (GD) and total porosity of the soil $\phi$ of the 9 points analyzed.

\begin{tabular}{cccccccccc}
\hline Point & A1 & A2 & A3 & A4 & A5 & A6 & A7 & A8 & A9 \\
\hline $\mathrm{D} g\left(\mathrm{~g} / \mathrm{cm}^{3}\right)$ & 1.31 & 1.25 & 1.29 & 1.47 & 1.45 & 1.38 & 1.42 & 1.35 & 1.40 \\
$\phi$ & 0.52 & 0.53 & 0.51 & 0.48 & 0.45 & 0.48 & 0.46 & 0.49 & 0.47 \\
\hline
\end{tabular}

Table 6. Values of shape and normalization parameters.

\begin{tabular}{cccccccccc}
\hline & A1 & A2 & A3 & A4 & A5 & A6 & A7 & A8 & A9 \\
\hline$\Theta \mathrm{s}\left(\mathrm{cm}^{3} / \mathrm{cm}^{3}\right)$ & 0.47 & 0.48 & 0.46 & 0.43 & 0.41 & 0.43 & 0.42 & 0.44 & 0.43 \\
$\mathrm{hg}(\mathrm{m})$ & -0.026 & -0.035 & -0.042 & -0.059 & -0.065 & -0.065 & -0.080 & -0.051 & -0.065 \\
$\mathrm{~N}$ & 2.12 & 2.12 & 2.12 & 2.13 & 2.13 & 2.13 & 2.13 & 2.12 & 2.13 \\
$\mathrm{Ks}\left({\left.\mathrm{m} . \mathrm{s}^{-1}\right)}^{6.24 \mathrm{E}-05}\right.$ & $1.26 \mathrm{E}-04$ & $2.92 \mathrm{E}-05$ & $5.03 \mathrm{E}-05$ & $8.99 \mathrm{E}-05$ & $3.59 \mathrm{E}-05$ & $4.64 \mathrm{E}-05$ & $4.66 \mathrm{E}-05$ & $3.29 \mathrm{E}-05$ \\
$\mathrm{H}$ & 19.29 & 19.44 & 19.4 & 18.45 & 18.53 & 18.83 & 18.66 & 19.04 & 18.75 \\
\hline
\end{tabular}


A.

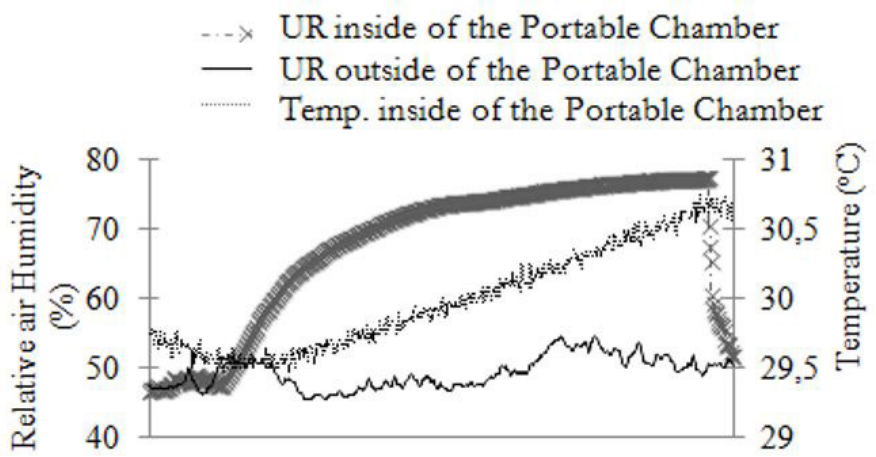

B.

B1 Vapor Density (11:32h $-11: 42 \mathrm{~h})$

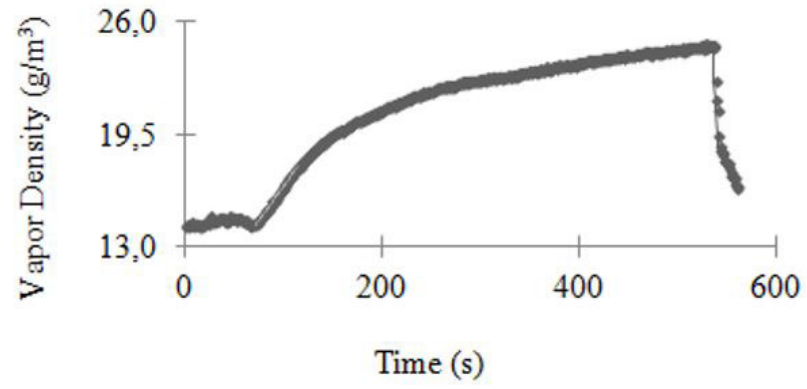

Figure 5. relative air humidity, air temperature (A) and vapor density, both measured in B1 at 11:32 am and 11:42 am (B), respectively.

Table 7. Minimum and maximum temperature and relative humidity inside the PC (UR PC (\%)), as well as the respectively mean slope of vapor density and evaporation (ET).

\begin{tabular}{|c|c|c|c|c|c|c|}
\hline \multirow[t]{2}{*}{ Group } & \multicolumn{2}{|c|}{$\begin{array}{l}\text { Temperature Portable Chamber } \\
\qquad\left({ }^{\circ} \mathrm{C}\right)\end{array}$} & \multicolumn{2}{|c|}{$\begin{array}{l}\text { UR Portable Chamber } \\
\qquad(\%)\end{array}$} & \multirow{2}{*}{$\begin{array}{c}\text { Maximum Slope } \\
\text { of Vapor Density } \\
\left(\mathrm{g} / \mathrm{m}^{3} \mathrm{~s}\right)\end{array}$} & \multirow[t]{2}{*}{$\operatorname{ET}(\mathrm{mm} / \mathrm{h})$} \\
\hline & Minimum & Maximum & Minimum & Maximum & & \\
\hline B1 & 29.47 & 43.29 & 28.93 & 84.8 & 8.75 & 0.16 \\
\hline B2 & 37.52 & 44.55 & 21.95 & 63.3 & 0.15 & 0.23 \\
\hline B3 & 38.25 & 46.24 & 18.96 & 38.77 & 0.05 & 0.07 \\
\hline B4 & 32.58 & 41.23 & 23.33 & 55.7 & 0.09 & 0.13 \\
\hline
\end{tabular}

properties. The water flow was in the liquid phase, due to the water level table being closer to the surface.

At point B3, the water table was $1.20 \mathrm{~m}$ and the average evaporation was $1.7 \mathrm{~mm} \cdot \mathrm{d}^{-1}$. Then, with a dry surface layer of the soil and the lower water table, the soil evaporation rate was lower and the flow occurred in the soil in two different ways: liquid water and vapor flow. In the condition of unsaturated soil or groundwater level at a deep depth, the process of evaporation also depends on the soil hydraulic properties, which are function of the structure and texture (SHOKRI; SALVUCCI, 2011). At point B3, close the A2, it was found the highest value of saturated hydraulic conductivity (Table 6).

The time of measurement with this method, between 11:32am and $2: 42 \mathrm{pm}$, can overestimate the value of the daily evaporation in the bare soil. Almeida (2006) evaluating the daily evaporation in four periods had verified that about $70 \%$ of it occurs in the second or third period of the day, that is, from $6 \mathrm{am}$ to $6 \mathrm{pm}$, on the region. The daily evaporation of 1.6 to $8.3 \mathrm{~mm} /$ day, with an average of $3.6 \mathrm{~mm} /$ day, results on about $1800 \mathrm{~mm} /$ year. That is the average range of potential annual evaporation of the bare soil of semi-arid region in Brazil. Silva and Souza (2011) obtained an average reference evapotranspiration value of $1,145.1 \mathrm{~mm} /$ year for the state of Pernambuco, using Penman-Monteith method. Souza et al. (2015) obtained actual evapotranspiration values of $1,277.5 \mathrm{~mm} /$ year for an area with caatinga vegetation. Rebouças indicates that the expected evaporation range for Northeast Brazil is between 1500 and $3000 \mathrm{~mm} /$ year. Krishnan et al. (2012) obtained evaporation values varying from 2.80 to $3.60 \mathrm{~mm} /$ day in the region of Arizona (1022 to $1314 \mathrm{~mm} /$ year).

\section{SISPAT Model}

The evolution of accumulated evaporation as a function of time obtained with the SiSPAT model simulation is presented in Figures 6A and 6B. The values of accumulated evaporation for the period of 7 days were $60.79 \mathrm{~mm}$ and $22.87 \mathrm{~mm}$ for the groundwater depth at $0.2 \mathrm{~m}$ (point A1) and $1.2 \mathrm{~m}$ (point A2), respectively. At the condition of the watertable at $0.20 \mathrm{~m}$ from the surface, the simulated average evaporation was $8.7 \mathrm{~mm} \cdot \mathrm{d}^{-1}$. When the water table was at $1.20 \mathrm{~m}$, the daily average evaporation simulated was $3.3 \mathrm{~mm} \cdot \mathrm{d}^{-1}$.

Therefore, on the dryer soil surface condition, the evaporation rate is, partly, controlled by the soil, in function of its capability to conduct water from the deeper layers to the surface. The greater is the thickness of the layer and deeper is the water table, more water is retained, that happens because it suffers influence of solar radiation.

Thus, it happened a contribution of water vapor flow when the water table was at a higher depth, giving priority to the process of heat transfer by conduction on evaporation quantification, according to Boulet et al. (1997). In dry soils, the evaporation of water in the soil occurs at acertain depth under the surface (SHOKRI; SALVUCCI, 2011). The surface is then deeply regulated by the depth of the evaporation zone and not by the surface water content.

It should be considered that the hydrodynamic characterization of the soil was performed only on the surface, what could have interfered on the results. For the water table nearest to the surface a higher evaporation was found, reaching $10.29 \mathrm{~mm}$ at the sixty 
A.

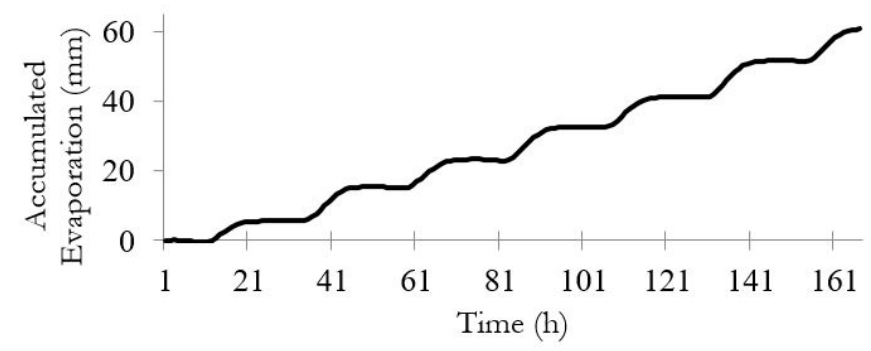

B.

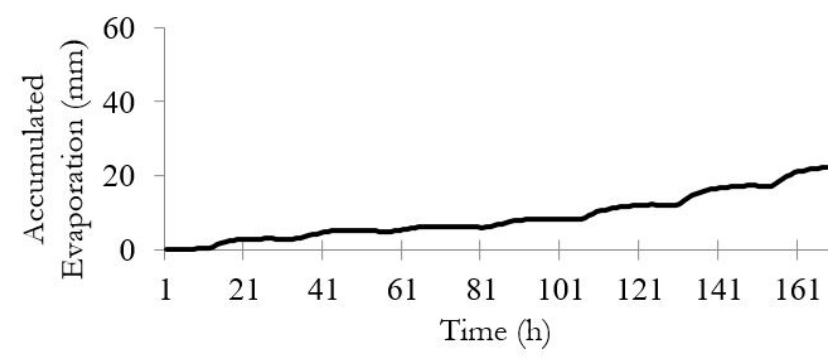

Figure 6. SiSPAT model accumulated evaporation $(\mathrm{mm})$ : water table at a depth of $0.2 \mathrm{~m}(\mathrm{~A})$ and $1.2 \mathrm{~m}(\mathrm{~B})$, respectively for points A1 and A2.

A.

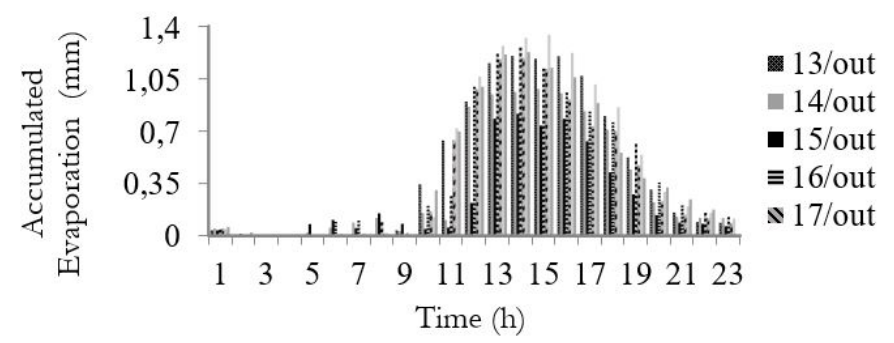

B.

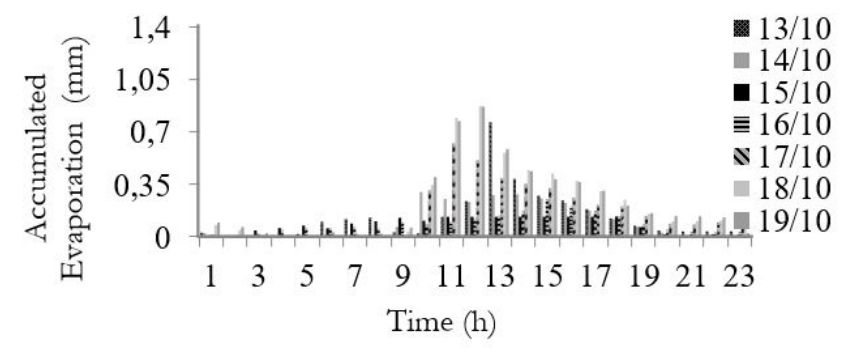

Figure 7. SiSPAT model estimated evaporation (mm): water table depth at $0.2 \mathrm{~m}(\mathrm{~A})$ and at $1.2 \mathrm{~m}(\mathrm{~B})$.

simulation day (Figure 6A). The evaporation increased rapidly from 10 am onwards, in all days simulated due to the solar radiation.

This simulation has verified that $79 \%$ of the evaporation occurred in the time interval of $6 \mathrm{am}$ to $6 \mathrm{pm}$. This value matches with the evaporation percentage founded by Almeida (2006), who has identified a value of $70 \%$. For the water table at $1.20 \mathrm{~m}$ it was found a lower evaporation, with a maximum of $5.1 \mathrm{~mm}$ at the last simulation day. The sharp increase in evaporation occurred from 10 am onwards, in all days of simulation, representing $81 \%$ of the bare soil simulation between 6 am and $6 \mathrm{pm}$ (Figures $7 \mathrm{~A}$ and $7 \mathrm{~B}$ ).

\section{Evaporation in the upstream area of the underground dam}

The first simulated condition with the water table at $0.2 \mathrm{~m}$, used the soil hydraulic properties of point A1 (Table 6), similar to the conditions applied to the Portable Chamber of group B2. The values found for evaporation with both methods differ at $1.43 \%$, which indicates that the estimation of evaporation by both methods are equivalent. The evaporation simulated on October 15th 2011 was $5.61 \mathrm{~mm} . \mathrm{d}^{-1}$, and the measured value through the application of the PC, of group B2, was $5.53 \mathrm{~mm} . \mathrm{d}^{-1}$.

The simulation that was performed when the watertable was at $1.20 \mathrm{~m}$ matches with the hydraulic soil conditions of point A2 (Table 5). At this point, the conditions are similar to the point B3, where the PC method was applied. The evaporation stimulated by the simulation in the SiSPAT on October 15th 2011 was $1.80 \mathrm{~mm} \cdot \mathrm{d}^{-1}$. The evaporation by the Portable Chamber method of group B3 was $1.72 \mathrm{~mm} . \mathrm{d}^{-1}$, with a difference of $4.44 \%$, meaning that there is an equivalence between the used methods.

The results may have suffered interference from the following conditions: dry period on the measurement with the Portable Chamber, acritical time of application of the Portable Chamber, the absence of continuous monitoring of the water table depth, atmospheric data used was located far from the study area $(35 \mathrm{Km})$. But the used methodologies considered important in a different area, although with similar condition sand intervening factors on the evaporation process, especially in semiarid regions, which are in general neglected by others simulation methods.

\section{CONCLUSIONS}

The SiSPAT model and the Portable Chamber (PC) method can be used to simulate different scenarios of management for the underground dam area, considering for example cultivation of crops.

The SiSPAT model produced results in consonance with the region and situations analyzed. There was equivalence in the application of the two methods, the simulation with SiSPAT and PC method, even for cases where the water table was in different depths.

\section{ACKNOWLEDGEMENTS}

The authors acknowledge the support of FACEPE (M.Sc scholarship), FINEP/CT-HIDRO (REHIDRO 1830), CNPq (PQ scholarships) and to ITEP for the meteorological data. 
This study was partially funded by the Conselho Nacional de Desenvolvimento Científico e Tecnológico (CNPq), grant No 465764/2014-2, the Coordenação de Aperfeiçoamento de Pessoal de Nível Superior - Brasil (CAPES), grant No 88887.136369/2017-00, and the Fundação de Amparo à Ciência e Tecnologia de Pernambuco (FACEPE), grant APQ-0498-3.07/17, through the project "National Observatory of Water and Carbon Dynamics in the Caatinga Biome (NOWCDCB).

\section{REFERENCES}

ALMEIDA, T. A. Avaliação do manejo de irrigação no âmbito da gestão participativa dos recursos hídricos no semiárido Pernambucano. 2006. $140 \mathrm{f}$. Dissertação (Mestrado). Programa de Pós-Graduação em Engenharia Civil, Universidade Federal de Pernambuco, Recife, 2006.

AMAZONAS, I. B.; ANTONINO, A. C. D.; SOARES, W. A.; LIMA, J. R. S.; MONTENEGRO, S. M. G. L. Estimativa da evaporação usando o modelo sispat em propriedade particular no município de São João - Pernambuco/Brasil. Revija za Geografijo, v. 32, n. 2, p. 63-76, 2015.

BALOGH, J.; NAGY, Z.; FOTI, S.; PINTER, K.; CZOBEL, S. Z.; PÉLI, E. R.; ACOSTA, M.; MAREK, M. V.; CSINTALAN, Z. S.; TUBA, Z. Comparison of $\mathrm{CO} 2$ and $\mathrm{H} 2 \mathrm{O}$ fluxes over grassland vegetations measured by the eddy-covariance technique and by open system chamber. Photosynthetica, v. 45, n. 2, p. 288-292, 2007. http://dx.doi.org/10.1007/s11099-007-0046-9.

BITTELLI, M.; VENTURA, F.; CAMPBELL, G. S.; SNYDER, R. L.; GALLEGATI, F.; PISA, P. R. Coupling of heat, water vapor, and liquid water fluxes to compute evaporation in bare soils. Journal of Hydrology, v. 362, n. 3-4, p. 191-205, 2008. http:// dx.doi.org/10.1016/j.jhydrol.2008.08.014.

BOULET, G.; BRAUD, I.; VAUCLIN, M. Study of the mechanisms of evaporation under arid conditions using a detailed model of the soil-atmosphere continuum. Application to the EFEDA I experiment. Journal of Hydrology, v. 193, n. 1-4, p. 114-141, 1997. http://dx.doi.org/10.1016/S0022-1694(96)03148-4.

BRAUD, I.; ANTONINO, A. C. D.; VAUCLIN, M.; THONY, J. L.; RUELLE, P. A Simple Soil Plant Atmosphere Transfer model (SiSPAT). Development and field verification. Journal of Hydrology, v. 166, n. 3-4, p. 213-250, 1995a. http://dx.doi.org/10.1016/00221694(94)05085-C.

BRAUD, I.; BARIAC, T.; BIRON, P.; VAUCLIN, M. Isotopic composition of bare soil evaporated water vapor Part II: Modeling of RUBIC IV experimental results. Journal of Hydrology, v. 369, n. 1-2, p. 17-19, 2009. http://dx.doi.org/10.1016/j.jhydrol.2009.01.038.

BRAUD, I.; DANTAS-ANTONINO, A. C.; VAUCLIN, M. A stochastic approach to studying the influence of the spatial variability of soil hydraulic properties on surface fluyes, temperarure and humidity. Journal of Hydrology, v. 165, n. 1-4, p. 283-310, $1995 \mathrm{~b}$. http://dx.doi.org/10.1016/0022-1694(94)02548-P.
BROOKS, R. H.; COREY, A. T. Hydraulic properties of porous media. Fort Collins: Colorado State University, 1964. 27 p. (Hydrology Paper, 3).

BURKART, S.; MANDERSCHEID, R.; WEIGEL, H. J. Design and performance of a portable gas exchange chamber system for CO2-and H2O-flux measurements in crop canopies. Environmental and Experimental Botany, v. 61, n. 1, p. 25-34, 2007. http://dx.doi. org/10.1016/j.envexpbot.2007.02.007.

CENTINARI, M.; PONI, S.; FILIPPETTTI, I.; MAGNANINI, E.; INTRIERI, C. Evaluation of an open portable chamber system for measuring cover crop water use in a vineyard and comparison with a mini-lysimeter. Agricultural and Forest Meteorology, v. 149, n. 11, p. 1975-1982, 2009. http://dx.doi.org/10.1016/j. agrformet.2009.07.005.

DUGAS, W. A.; REICOSKY, D. C.; KINIRY, J. R. Chamber and micrometeorological measurements of $\mathrm{CO} 2$ and $\mathrm{H} 2 \mathrm{O}$ fluxes for three C4 grasses. Agricultural and Forest Meteorology, v. 83, n. 1-2, p. 113-133, 1997. http://dx.doi.org/10.1016/S0168-1923(96)02346-5.

EMBRAPA - EMPRESA BRASILEIRAN DE PESQUISA AGROPECUARIA. Serviço Nacional de Levantamento e Conservação dos Solos-Manual de métodos de análises de solo. Rio de Janeiro: EMBRAPA, 1997. 412 p.

HEIJMANS, M. M. P. D.; ARP, W. J.; CHAPIN, F. S. 3rd. Carbon dioxide and water vapour exchange from understory species in boreal forest. Agricultural and Forest Meteorology, v. 123, n. 3-4, p. 135-147, 2004. http://dx.doi.org/10.1016/j.agrformet.2003.12.006.

KELLER FILHO, T.; ASSAD, E. D.; LIMA, P. R. S. R. Regiões pluviometricamente homogêneas no Brasil. Pesquisa Agropecuária Brasileira, v. 40, n. 4, p. 311-322, 2005. http://dx.doi.org/10.1590/ S0100-204X2005000400001.

KRISHNAN, P.; MEYERS, T. P.; SCOTTT, R. L.; KENNEDY, L.; HEUER, M. Energy exchange and evapotranspiration over two temperate semi-arid grassland in North America. Agricultural and Forest Meteorology, v. 153, p. 31-44, 2012. http://dx.doi.org/10.1016/j. agrformet.2011.09.017.

LASAGE, R., AERTS, J. C. J. H., MUTISO, G. C., \& DE VRIES, A. Potential for community based adaptation to droughts: Sand dams in Kitui, Kenya. Physics and Chemistry of the Earth, v. 33, n. 1, p. $67-73,2008$.

LASSABATÈRE, L.; ANGULO-JARAMILLO, R.; SORIA UGALDE, J. M.; CUENCA, R.; BRAUD, I.; HAVERKAMP, R. Beerkan estimation of soil transfer parameters through infiltration experiments - BEST. Soil Science Society of America Journal, v. 70, n. 2, p. 521-532, 2006. http://dx.doi.org/10.2136/sssaj2005.0026.

LUO, C.; WANG, Z.; SAUER, T. J.; HELMERS, M. J.; HORTON, R. Portable canopy chamber measurements of evapotranspiration incorn, soybean, and reconstructed prairie. Agricultural Water 
Management, v. 198, p. 1-9, 2018. http://dx.doi.org/10.1016/j. agwat.2017.11.024.

MACKAY, R.; MONTENEGRO, A.; MONTENEGRO, S.; WONDEREN, J. V. Alluvial Aquifer indicators for small-scale irrigation in northeast Brazil. In: WEBB, B.; HIRATA, R.; KRUSE, E.; VRBA, J. Sustainability of Groundwater Resources and its indicators. Oxfordshire: IAHS, 2005. (IAHS publication, 302).

MCLEOD, M. K.; DANIEL, H.; FAULKNER, R.; MURISON, R. Evaluation of an enclosed portable chamber to measure crop and pasture actual evapotranspiration at small scale. Agricultural Water Management, v. 67, n. 1, p. 15-34, 2004. http://dx.doi.org/10.1016/j. agwat.2003.12.006.

MONTENEGro, S. M. G. L.; MONTENEGRO, A. A. A. Aproveitamento sustentável de aqǘferos aluviais no semi-árido. In: CABRAL, J. J. S. P.; FERREIRA, J. P. L.; MONTENEGRO, S. M. G. L.; COSTA, W. D. (Org.). Água subterrânea: aqü̈feros costeiros $e$ aluviôes, vulnerabilidade e aproveitamento. 1. ed. Recife: Editora Universitária UFPE, 2004. v. 1, p. 44-102.

MORET, D.; BRAUD, I.; ARRÚE, J. L. Water balance simulation of a dryland soil during fallow under conventional and conservation tillage in semiarid Aragon, Northeast Spain. Soil \& Tillage Research, v. 92 , n. $1-2$, p. 251-263, 2007. http://dx.doi.org/10.1016/j. still.2006.03.012.

PICKERING, N. B.; JONES, J. W.; BOOTE, K. J. a, Jones, J.W., Boote, K.J. Evaluation of the portable chamber technique for measuring canopy gas exchange by crops. Agricultural and Forest Meteorology, v. 63, n. 3-4, p. 239-254, 1993. http://dx.doi. org/10.1016/0168-1923(93)90062-M.

PONI, S.; MAGNANINI, E.; REBUCCI, B. An automated chamber system for measurements of whole-vine gas-exchange. HortScience, v. 32, p. 64-67, 1997.

QUILIS, R. O.; HOOGMOED, M.; ERTSEN, M.; FOPPEN, J. W.; HUT, R.; VRIES, A. Measuring and modeling hydrological processes of sand-storage dams on different spatial scales. Physics and Chemistry of the Earth, Parts A/B/C, v. 34, n. 4, p. 289-298, 2009. http://dx.doi.org/10.1016/j.pce.2008.06.057.

RAZ-YASEEF, N.; ROTENBERG, E.; YAKIR, D. Effects of spatial variations in soil evaporation caused by tree shading on water flux partitioning in a semi-arid pine forest. Agricultural and Forest Meteorology, v. 150, n. 3, p. 454-462, 2010. http://dx.doi. org/10.1016/j.agrformet.2010.01.010.

SHOKRI, N.; SALVUCCI, G. D. Evaporation from porous media in the presence of a water table. Vadose Zone Journal, v. 10, n. 4, p. 1309-1318, 2011. http://dx.doi.org/10.2136/vzj2011.0027.

SILVA, A. P. N.; SOUZA, L. R. Estimativa de evapotranspiração de referência no Semiárido Pernambucano. Engenharia Ambiental - Espírito Santo do Pinhal, v. 8, n. 4, p. 3-22, out./dez. 2011.
SILVA, R. C.; ALVALÁ, R. C. S.; MANZI, A. O., SOUZA, A. Estimativa da radiação de onda longa atmosférica no Pantanal sul matogrossense durante o período seco de 1999. In: CONGRESSO BRASILEIRO DE METEOROLOGIA, 12., 2002, Foz do Iguaçu. Anais... Foz do Iguaçu: Sociedade Brasileira de Meteorologia, 2002. p. 2817-2826.

SOARES, W. A. Fluxos de água e de energia em feijão Macassar e Mamona no Nordeste do Brasil. 2009. Tese (Doutorado). Universidade Federal de Pernambuco, Recife, 2009.

SOARES, W. A.; ANTONINO, A. C. D.; LIMA, J.; SOUZA, E.; MONTENEGRO, S.; LIRA, C. Simulação dos fluxos de água e de energia na microbacia hidrográfica da represa Vaca Brava no Brejo Paraibano. Revista Brasileira de Recursos Hidricos, v. 18, n. 4, p. 185-196, 2013. http://dx.doi.org/10.21168/rbrh.v18n4.p185-196.

SOUZA, E. S.; ANTONINO, A. C. D.; ANGULO-JARAMILLO, R.; NETTO, A. M. Caracterização hidrodinâmica de solos: Aplicação do método Beerkan. Revista Brasileira de Engenharia Agricola e Ambiental, v. 12, n. 2, p. 128-135, 2008. http://dx.doi. org/10.1590/S1415-43662008000200004.

SOUZA, E. S.; ANTONINO, A. C. D.; HECK, R. J.; MONTENEGRO, S. M. G. L.; LIMA, J. R. S.; SAMPAIO, E. V. S. B.; ANGULO-JARAMILLO, R.; VAUCLIN, M. Effect of crusting on the physical and hydraulic properties of a soil cropped with Castor beans (Ricinus communis L.) in the northeastern region of Brazil. Soil \& Tillage Research, v. 141, p. 55-61, 2014. http:// dx.doi.org/10.1016/j.still.2014.04.004.

SOUZA, R. M. S.; SOUZA, E. S.; ANTONINO, A. C. D.; LIMA, J. R. S. Balanço hídrico em área de pastagem no semiárido pernambucano. Revista Brasileira de Engenharia Agrícola e Ambiental (Online), v. 19, n. 5, p. 449-455, 2015. http://dx.doi.org/10.1590/1807-1929/ agriambi.v19n5p449-455.

STANNARD, D. I. Use of a hemispherical chamber for measurement of evapotranspiration. U.S. Geological Survey Open-File Report, p. 88-452, 1988.

UNITED KINGDOM. DFID - Department for International Development. Project: R8333. Sustainable Use of Groundwater in the Semi-arid Ribbon Valleys of Northeast Brazil Final Technical Report. Cambridge: Mott MacDonald, 2004.

VAN GENUCHTEN, M. T. A closed-form equation for predicting the hydraulic conductivity of unsaturated soils. Soil Science Society of America Journal, v. 44, p. 892-898, 1980.

\section{Authors contributions}

Fernandha Batista Lafayette: Manuscript structure, literature review, methods and analysis of the results. 
Suzana Maria Gico Lima Montenegro: Study orientation, literature review and methods.

Artur Paiva Coutinho: Download of the meteorological data from ITEP and literature review and technical review of the manuscript.

Willames Soares: Analysis of the results from SiSPAT model and technical review of the manuscript.
Antônio Celso Dantas Antonino: Study orientation, analysis of the results and technical review of the manuscript.

Bernardo Barbosa da Silva: Study orientation about Portable Chamber method.

Ana Emília Carvalho de Gusmão da Cunha Rabelo: Analysis of the results and discussion. 